OPTIMUM. STUDIA EKONOMICZNE NR 4 (88) 2017

\author{
dr Dominik ŚLIWICKI \\ Urząd Statystyczny w Bydgoszczy, Wyższa Szkoła Gospodarki w Bydgoszczy \\ e-mail: d.sliwicki@stat.gov.pl
}

DOI: $10.15290 /$ ose.2017.04.88.12

\title{
SZACUNKI LUKI PLACOWEJ W POLSCE W UJĘCIU REGIONALNYM
}

\begin{abstract}
Streszczenie
Celem artykułu jest określenie wpływu metody szacunku średniego wynagrodzenia na wielkość oraz kierunek luki płacowej w Polsce w ujęciu regionalnym. Luka płacowa pomiędzy mężczyznami a kobietami jest negatywnym zjawiskiem badanym i opisywanym w coraz szerszym kontekście. Środowiska naukowe oraz praktycy polityki społecznej wykształcili metody pozwalające na pomiar wielkości luki. Metodologia stosowana przez organy Unii Europejskiej dostarcza tzw. nieskorygowanych szacunków luki płacowej, czyli takich, które nie uwzględniają indywidualnych cech mężczyzn i kobiet. W artykule zaprezentowano szacunki luki płacowej według województw, uzyskane dzięki metodologii europejskiej z wykorzystaniem ośmiu różnych wielkości charakteryzujących przeciętne wynagrodzenia osiagane przez mężczyzn i kobiety.
\end{abstract}

Słowa kluczowe: luka płacowa, dyskryminacja

\section{ESTIMATES OF GENDER PAY GAP IN POLAND IN REGIONAL TERMS}

\section{Summary}

The aim of the paper is to determine the impact of average pay estimation on the size and direction of the pay gap in Poland in regional terms. The pay gap between men and women is a negative phenomenon that has been analysed and described in an increasingly broader context. Scientific communities and social policy practitioners have developed methods for measuring the size of the gap. The methodology used by the bodies of the European Union allows researchers to obtain the so called unadjusted wage gap estimates, i.e. ones that do not take into account the individual characteristics of men and women. The paper presents the wage gap estimates by province, calculated on the basis of the European methodology, with the use of eight different variables which characterise the average pay earned by men and women.

Key words: gender pay gap, discrimination

JEL classification: C10, J31, J71 


\section{Wstęp}

Różnica w wynagrodzeniach pomiędzy mężczyznami i kobietami jest określana mianem luki płacowej. Wyjaśnienie przyczyn luki płacowej w gospodarce i społeczeństwie jest zagadnieniem bardzo złożonym, wynikającym z wielu powiązanych ze sobą czynników zarówno kulturowych, jak i społecznych oraz ekonomicznych i psychologicznych. Powszechnie uznaje się, że kobiety osiagają niższe wynagrodzenia od mężczyzn, co skutkuje otrzymywaniem przez nie znacznie niższych świadczeń emerytalnych po zakończeniu aktywności zawodowej. Lukę płacową na ogół postrzega się jako zjawisko o charakterze negatywnym o bardzo skomplikowanym podłożu. Z tego względu jest przedmiotem badań na gruncie ekonomii, socjologii, filozofii, zarządzania $\mathrm{i}$ innych nauk. Zagadnienie to coraz częściej jest także poruszane w dyskusjach wśród praktyków życia społecznego i gospodarczego. Złożoność samego zjawiska oraz coraz szerszy dostęp do danych statystycznych zaowocowały wypracowaniem metod pomiaru luki płacowej, które w mniej lub bardziej zobiektywizowany sposób dostarczają informacji o jej wielkości. Zasadniczy problem pomiaru luki płacowej polega na tym, że wypracowane metody nie daja jednoznacznych wyników, a sam wskaźnik jest wrażliwy na wartości wejściowe.

Celem artykułu jest określenie wpływu metody szacunku średniego wynagrodzenia na wielkość oraz kierunek luki płacowej w postaci nieskorygowanej, czyli takiej, która nie uwzględnia cech społeczno-demograficznych i zawodowych pracowników. Problem pomiaru luki płacowej w ujęciu regionalnym został przeanalizowany $z$ wykorzystaniem danych zebranych przez statystykę publiczną w ramach badania struktury wynagrodzeń według zawodów.

\section{Przyczyny luki płacowej}

Rozpatrując przyczyny luki płacowej, można wskazać czynniki: ekonomiczne, społeczne, kulturowe oraz psychologiczne. W szczególności czynnikami kształtującymi lukę płacową są poniżej przedstawione.

1. Segregacja zawodowa, która definiowana jest jako koncentracja kobiet i mężczyzn w różnych zawodach [Russel, Smyth, O'Connel, 2010]. Może ona przybierać dwie formy. Horyzontalna segregacja polega na nadreprezentacji kobiet w zawodach typowo kobiecych, najczęściej słabo opłacanych i niedowartościowanych [Alksnis, Desmarais, Curtis, 2008] (np. pielęgniarki). Segregacja wertykalna $z$ kolei jest związana z prestiżem i pozycją zawodowa. Wiąże się z tym, że mężczyźni zajmują wyższe stanowiska i tym samym otrzymują wyższe wynagrodzenia niż ich kobiece odpowiedniki [Warren, Rowlingson, Whyley, 2001] (np. niski odsetek kobiet na stanowiskach kierowniczych).

2. Praca w niepełnym wymiarze czasu pracy, która jest wybierana częściej przez kobiety niż przez mężczyzn [Walby, Olsen, 2002]. Wybór ten wynika przede wszystkim z konieczności zapewnienia opieki nad małoletnimi dziećmi lub innymi członkami rodziny. Niekiedy większy ciężar wychowywania dzieci 
bądź opieki nad starszymi członkami rodzin spoczywa właśnie na kobietach. Ponadto, oferty pracy w niepełnym wymiarze czasu pracy zwykle są oferowane w zawodach uznawanych jako kobiece.

3. Różna treść pracy wynikająca z podziału na prace kobiece - lżejsze, łatwiejsze, wymagające mniejszych umiejętności i męskie - cięższe, trudniejsze, wymagające wyższych umiejętności. Zróżnicowanie charakteru pracy kobiet może być efektem braku bądź posiadania stosunkowo małego doświadczenia zawodowego związanego z pozostawaniem poza formalnym rynkiem pracy (przerwy w zatrudnieniu) i wykonywania prac obejmujących prowadzenie gospodarstwa domowego. Prace te i związane z nimi doświadczenie nie są wyceniane przez rynek pracy, co często stanowi przeszkodę w dostępie do określonych zawodów [Baron, Cobb-Clark, 2010].

4. Preferencje pracodawców dotyczące dyspozycyjności - pracodawcy preferuja pracowników dyspozycyjnych, a dyspozycyjność kobiet na rynku pracy jest wyceniana przez rynek pracy słabiej aniżeli dyspozycyjność mężczyzn. Stąd kobiety decydują się na poszukiwanie zatrudnienia w zawodach, które ułatwiają im pogodzenie obowiązków rodzinnych i zawodowych, kosztem dyspozycyjności i niższych wynagrodzeń [Lisowska, 2012].

5. Czynniki psychologiczne przejawiajace się w akceptowaniu przez kobiety niższych wynagrodzeń z uwagi na przekonanie o mniejszej sile przetargowej i negocjacyjnej na rynku pracy [Lisowska, 2012].

Do głównych przyczyn różnicy w wynagrodzeniach mężczyzn i kobiet Komisja Europejska zalicza:

- dyskryminację w miejscu pracy, której wyrazem jest mniej korzystne traktowaniem kobiet w stosunkach pracy - tzw. dyskryminacja bezpośrednia. Dyskryminacja może również wynikać z prowadzonej polityki lub praktyki, która mimo że nie została stworzona do tego celu, powoduje nierówne traktowanie mężzyzn i kobiet;

- $\quad$ wykonywanie przez mężczyzn i kobiety różnych zawodów w rozmaitych sektorach;

- $\quad$ praktyki w miejscach pracy oraz systemy płac, które moga prowadzić do różnych stawek wynagradzania kobiet i mężczyzn;

- $\quad$ niedocenianie pracy i umiejętności kobiet;

- niewielka liczba kobiet na stanowiskach zarządczych i kierowniczych;

- $\quad$ czynniki kulturowe, których następstwem jest tradycyjne postrzeganie ról kobiet i mężzzyzn w społeczeństwie;

- równoważenie obowiązków zawodowych i rodzinnych - kobiety pracuja krócej oraz często $\mathrm{w}$ niepełnym wymiarze czasu pracy w celu łączenia obowiązków rodzinnych z działalnością zarobkową [Przeciiwdziatanie różnicy w wynagrodzeniu..., 2014]. 


\section{Pomiar luki płacowej}

Rozważania naukowe nad zjawiskiem luki płacowej doprowadziły do wykształcenia wielu metod szacowania wskaźnika GPG, wśród których najczęściej wymienia się metodę Oaxaca-Blindera [Oaxaca, 1973; Blinder, 1973; Reszke, 1991; Stanley, Jarrel, 1998; Brainerd, 2000; Newell, Reilly 2001; Adamchik, Bedi, 2003; Grajek, 2003; Kalinowska-Nawrotek, 2005; Weichselbaumer, Winter-Ebmer, 2005; Magda, Szydłowski, 2008; Słoczyński, 2012; Śliwicki, Ryczkowski, 2014; Śliwicki, 2015] oraz metody oparte na mechanizmach łączenia danych dotyczących mężczyzn i kobiet [Frölich, 2007; Nopo, 2008]. Najczęściej metody te dają skorygowane szacunki wskaźnika GPG.

Badanie luki płacowej w statystyce europejskiej opiera się na danych zebranych w ramach badania struktury wynagrodzeń, które, zgodnie z wytycznymi EUROSTAT-u, musi być realizowane co cztery lata. W Polsce badanie to jest przeprowadzane w cyklu dwuletnim i dostarcza informacji m.in. o przeciętnych i średnich godzinowych wynagrodzeniach pracowników w podziale na: płeć, wiek, wykształcenie, staż pracy, zawód, rodzaj umowy o pracę, system czasu pracy, wielkość podmiotu zatrudniającego, sektor własności.

W ujęciu operacyjnym luka płacowa jest mierzona za pomocą wskaźnika Gender Pay Gap (GPG) i wyrażana w ujęciu względnym za pomocą formuły [The gender pay gap..., 2010]:

$$
G P G=\frac{W_{m}-W_{k}}{W_{m}} 100[\%]
$$

gdzie:

$W_{m}-$ wynagrodzenie mężczyzn,

$W_{k}$ - wynagrodzenie kobiet.

Konkretna wartość wskaźnika GPG informuje o ile procent wynagrodzenie kobiet jest mniejsze (gdy wartość jest dodatnia) albo większe (gdy wartość jest ujemna) od wynagrodzenia mężczyzn. Szacunki tego wskaźnika będą różnić się w zależności od tego, co zostanie przyjęte jako szacunki wynagrodzeń mężczyzn i kobiet. W metodologii stosowanej w Unii Europejskiej za podstawę szacunków GPG przyjmuje się średnie stawki godzinowe wynagrodzenia brutto. Ponadto w szacunkach GPG bierze się pod uwage tylko podmioty zatrudniające przynajmniej 10 osób, które nie prowadzą działalności w zakresie: rolnictwa, leśnictwa, łowiectwa i rybactwa (sekcja A, według Polskiej Klasyfikacji Działalnościํ) oraz administracji publicznej i obrony narodowej, obowiązkowego zabezpieczenia społecznego (sekcja O, według Polskiej Klasyfikacji Działalności).Wskaźnik przedstawiony za pomoca formuły (1) odzwierciedla nieskorygowaną różnicę w wynagrodzeniach mężczyzn i kobiet, ponieważ nie ujmuje czynników,

1 PKD to Polska Klasyfikacja Działalności wprowadzona Rozporządzeniem Rady Ministrów z dnia 24 grudnia 2007 roku w sprawie Polskiej Klasyfikacji Działalności (PKD) (Dz.U. 251, poz.1885). Klasyfikacja ta jest umownie przyjętym, hierarchicznie usystematyzowanym podziałem zbioru rodzajów działalności społeczno-gospodarczej, jakie realizuja jednostki (podmioty gospodarcze). 
które mogą na tę różnicę wpływać, takich jak np.: wykształcenie, staż pracy, rodzaj wykonywanej pracy, złożoność stanowiska pracy, zawód, skłonność do podejmowania ryzyka i inne czynniki, które moga mieć charakter zarówno ilościowy, jak i jakościowy.

\section{Dane statystyczne wykorzystane do oszacowań wskaźnika Gender Pay Gap}

Wskaźnik Gender Pay Gap przyjmuje różne wartości w zależności od tego, co zostanie przyjęte jako szacunek przeciętnych wynagrodzeń dla mężczyzn i kobiet. Dane statystyczne, będące podstawą obliczeń, zostały zebrane w ramach badania struktury wynagrodzeń, realizowanego na formularzu Z-12 („Sprawozdanie o strukturze wynagrodzeń według zawodów”) za 2014 rok. Na formularzu tym są zbierane dane o cechach osobowych pracowników, tj.: zawodzie, płci, poziomie ukończonego wykształcenia, rodzaju umowy o pracę, systemu czasu pracy, roku i miesiącu urodzenia, stażu pracy a także o czasie pracy i wynagrodzeniach osobowych ogólem brutto za październik badanego roku i za cały badany rok. W dokonanej analizie wykorzystano dane dotyczace:

- stawki godzinowej wynagrodzenia za czas nominalny w październiku (SGN_PAZ);

- $\quad$ stawki godzinowej wynagrodzenia ogółem za październik (SGO_PAZ);

- $\quad$ stawki godzinowej wynagrodzenia za czas nominalny w roku (SGN_ROK);

- $\quad$ stawki godzinowej wynagrodzenia ogółem brutto za rok (SGO_ROK);

- $\quad$ wynagrodzenia za czas nominalny za październik przeliczonego do wynagrodzenia za czas nominalny za pełen etat (TWN_PAZ);

- $\quad$ wynagrodzenia ogółem za październik przeliczonego do wynagrodzenia ogółem za pełen etat (TWO_PAZ);

- $\quad$ wynagrodzenia za czas nominalny za rok przeliczonego do wynagrodzenia za czas nominalny za pełen etat (TWN_ROK);

- $\quad$ wynagrodzenia ogółem za rok przeliczonego do wynagrodzenia ogółem za pelen etat (TWO_ROK).

Szczegółowy opis transformacji zmiennych formularzowych w zmienne służące naliczeniu wskaźnika Gender Pay Gap zawiera tabela 1. Otrzymane wyniki stanowiły nieskorygowane szacunki luki płacowej, z uwagi na to, że nie uwzględniały cech demograficzno-zawodowych pracowników. 
TABELA 1.

Transformacje zmiennych wykorzystywanych do oszacowania wskaźnika Gender Pay Gap

\begin{tabular}{|c|c|c|}
\hline $\begin{array}{c}\text { Pola } \\
\text { formu- } \\
\text { larzowe }\end{array}$ & Opis pola & $\begin{array}{l}\text { Pola przeliczone do pełnego etatu } \\
\text { i pełnego miesiąca/roku }\end{array}$ \\
\hline ----- & $\begin{array}{c}\text { Pole przeliczające do pełnego etatu i } 23 \\
\text { dni roboczych w październiku }\end{array}$ & $W S K \_C=\frac{4,6 * C 3}{C 4+C 6}$ \\
\hline$C 1$ & Wskaźnik wymiaru etatu w październiku & $T C 1=1,000$ \\
\hline$C 2$ & Liczba dni roboczych w październiku & $T C 2=23$ \\
\hline C3 & $\begin{array}{l}\text { Tygodniowa liczba godzin obowiązko- } \\
\text { wego pełnego wymiaru czasu pracy }\end{array}$ & $T C 3=4,6 * C 3$ \\
\hline$C 4$ & $\begin{array}{c}\text { Czas faktycznie przepracowany w godzi- } \\
\text { nach nominalnych w październiku }\end{array}$ & $T C 4=T C 3-T C 6$ \\
\hline C5 & $\begin{array}{c}\text { Czas faktycznie przepracowany w godzi- } \\
\text { nach nadliczbowych }\end{array}$ & $C 5$ \\
\hline C6 & Czas nieprzepracowany ogółem & $T C 6=C 6 * W S K_{-} C$ \\
\hline$C 7$ & $\begin{array}{c}\text { Czas nieprzepracowany, opłacony tylko } \\
\text { przez zakład pracy }\end{array}$ & $T C 7=C 7 * W S K_{-} C$ \\
\hline$C 8$ & $\begin{array}{c}\text { Wynagrodzenia osobowe ogółem brutto } \\
\text { za październik }\end{array}$ & $T C 8=T C 9+C 13$ \\
\hline$C 9$ & $\begin{array}{c}\text { Wynagrodzenie za październik za czas } \\
\text { nominalny (bez nagród i premii } \\
\text { uznaniowych) }\end{array}$ & $T C 9=C 9 * W S K_{-} C * \frac{C 4+C 6}{C 4+C 7}$ \\
\hline$C 10$ & $\begin{array}{c}\text { Wynagrodzenie zasadnicze za paździer- } \\
\text { nik }\end{array}$ & $T C 10=C 10 * W S K_{-} C * \frac{C 4+C 6}{C 4+C 7}$ \\
\hline$C 11$ & Dodatki za pracę zmianową & $T C 11=C 11 * W S K_{-} C * \frac{C 4+C 6}{C 4+C 7}$ \\
\hline$C 12$ & Premie regulaminowe & $T C 12=C 12 * W S K_{-} C * \frac{C 4+C 6}{C 4+C 7}$ \\
\hline$C 13$ & $\begin{array}{c}\text { Wynagrodzenie za pracę w godzinach } \\
\text { nadliczbowych }\end{array}$ & $C 13$ \\
\hline ----- & $\begin{array}{l}\text { Pole przeliczające do pełnego etatu } \\
\text { i } 250 \text { dni roboczych w } 2014 \text { roku }\end{array}$ & $W S K_{-} D=\frac{250 * \frac{D 3}{D 2}}{D 4+D 6}$ \\
\hline$D 1$ & Roczny wskaźnik wymiaru czasu pracy & $T D 1=12,000$ \\
\hline$D 2$ & Liczba dni roboczych w 2014 roku & $T D 2=250$ \\
\hline D3 & $\begin{array}{c}\text { Roczna liczba godzin obowiazkowego } \\
\text { pełnego wymiaru czasu pracy }\end{array}$ & $T D 3=250 * \frac{D 3}{D 2}$ \\
\hline D4 & $\begin{array}{c}\text { Czas faktycznie przepracowany w godzi- } \\
\text { nach nominalnych w roku }\end{array}$ & $T D 4=T D 3-T D 6$ \\
\hline
\end{tabular}




\begin{tabular}{|c|c|c|}
\hline $\begin{array}{c}\text { Pola } \\
\text { formu- } \\
\text { larzowe }\end{array}$ & Opis pola & $\begin{array}{l}\text { Pola przeliczone do pełnego etatu } \\
\text { i pełnego miesiąca/roku }\end{array}$ \\
\hline D5 & $\begin{array}{c}\text { Czas faktycznie przepracowany w godzi- } \\
\text { nach nadliczbowych w roku }\end{array}$ & $D 5$ \\
\hline D6 & $\begin{array}{c}\text { Czas nieprzepracowany (bez dni wolnych } \\
\text { od pracy) ogółem w roku }\end{array}$ & $T D 6=D 6 * W S K_{-} D$ \\
\hline D7 & $\begin{array}{c}\text { Czas nieprzepracowany (bez dni wolnych } \\
\text { od pracy) opłacony tylko przez zakład } \\
\text { pracy w roku }\end{array}$ & $T D 7=D 7 * W S K_{-} D$ \\
\hline D8 & $\begin{array}{c}\text { Czas nieprzepracowany (bez dni } \\
\text { wolnych od pracy) opłacony tylko przez } \\
\text { zakład pracy za przestoje ekonomiczne } \\
\text { w roku }\end{array}$ & $T D 8=D 8 * W S K_{-} D$ \\
\hline D9 & $\begin{array}{c}\text { Liczba dni urlopów wypoczynkowych } \\
\text { wykorzystanych w ciagu roku }\end{array}$ & $T D 9=D 9 * W S K \_D$ \\
\hline$D 10$ & $\begin{array}{c}\text { Wynagrodzenia osobowe ogółem brutto } \\
\text { za rok } \\
\end{array}$ & $T D 10=T D 11+T D 14$ \\
\hline$D 11$ & $\begin{array}{l}\text { Wynagrodzenie za rok za czas } \\
\text { nominalny }\end{array}$ & $\begin{array}{rl}T D 11=D 11 & * W S K_{-} D \\
& * \frac{D 4+D 6}{D 4+D 7-D 8}\end{array}$ \\
\hline$D 12$ & Premie regulaminowe za rok & $\begin{array}{rl}T D 12=D 12 & * W S K \_D \\
& * \frac{D 4+D 6}{D 4+D 7-D 8}\end{array}$ \\
\hline$D 13$ & Nagrody i premie uznaniowe za rok & $\begin{array}{rl}T D 13=D 13 & * W S K \_D \\
& * \frac{D 4+D 6}{D 4+D 7-D 8}\end{array}$ \\
\hline$D 14$ & $\begin{array}{l}\text { Wynagrodzenie za prace w godzinach } \\
\text { nadliczbowych }\end{array}$ & $D 14$ \\
\hline$D 15$ & $\begin{array}{l}\text { Honoraria mające charakter } \\
\text { wynagrodzenia pracowniczego za rok }\end{array}$ & $\begin{array}{rl}T D 15=D 15 & * W S K \_D \\
& * \frac{D 4+D 6}{D 4+D 7-D 8}\end{array}$ \\
\hline$D 16$ & $\begin{array}{c}\text { Dodatkowe wynagrodzenia roczne dla } \\
\text { pracowników jednostek sfery } \\
\text { budżetowej }\end{array}$ & $\begin{array}{rl}T D 16=D 16 & * W S K \_D \\
& * \frac{D 4+D 6}{D 4+D 7-D 8}\end{array}$ \\
\hline$D 17$ & $\begin{array}{c}\text { Wypłaty z tytułu udziału w zysku lub } \\
\text { w nadwyżce bilansowej w spółdzielniach }\end{array}$ & $\begin{array}{rl}T D 17=D 17 & * W S K \_D \\
& * \frac{D 4+D 6}{D 4+D 7-D 8}\end{array}$ \\
\hline ----- & $\begin{array}{l}\text { Przeliczony, nominalny czas pracy za } \\
\text { październik }\end{array}$ & $T C N \_P A Z=T C 4+T C 6$ \\
\hline 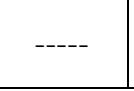 & $\begin{array}{c}\text { Przeliczony czas pracy ogółem za paź- } \\
\text { dziernik }\end{array}$ & $T C O \_P A Z=T C N \_P A Z+C 5$ \\
\hline
\end{tabular}




\begin{tabular}{|c|c|c|}
\hline $\begin{array}{c}\text { Pola } \\
\text { formu- } \\
\text { larzowe }\end{array}$ & Opis pola & $\begin{array}{c}\text { Pola przeliczone do pełnego etatu } \\
\text { i pełnego miesiąca/roku }\end{array}$ \\
\hline ----- & $\begin{array}{l}\text { Przeliczony, nominalny czas pracy } \\
\text { w roku }\end{array}$ & $T C N \_R O K=T D 4+T D 6$ \\
\hline----- & Przeliczony czas pracy ogółem za rok & $T C O \_R O K=T C N \_R O K+D 5$ \\
\hline ----- & $\begin{array}{l}\text { Przeliczone wynagrodzenie za czas prze- } \\
\text { pracowany w godzinach nominalnych za } \\
\text { październik }\end{array}$ & $\begin{array}{l}T W N_{-} P A Z \\
=T C 9 \\
+\frac{(T D 13+T D 15+T D 16+T D 17)}{12}\end{array}$ \\
\hline ----- & $\begin{array}{l}\text { Przeliczone wynagrodzenie ogółem za } \\
\text { październik }\end{array}$ & $T W O \_P A Z=T W N \_P A Z+C 13$ \\
\hline ----- & $\begin{array}{c}\text { Przeliczone wynagrodzenie za czas prze- } \\
\text { pracowany w godzinach nominalnych za } \\
\text { rok }\end{array}$ & $\begin{array}{rl}T W N_{-} R O K=T D & 11+T D 15 \\
& +T D 16+T D 17\end{array}$ \\
\hline & $\begin{array}{l}\text { Przeliczone wynagrodzenie ogółem za } \\
\text { rok }\end{array}$ & $T W O_{-} R O K=T W N \_R O K+D 14$ \\
\hline- & $\begin{array}{c}\text { Stawka godzinowa wynagrodzenia ogó- } \\
\text { łem za październik }\end{array}$ & $S G O_{-} P A Z=\frac{T W O_{-} P A Z}{T C O_{-} P A Z}$ \\
\hline & $\begin{array}{c}\text { Stawka godzinowa wynagrodzenia za } \\
\text { czas przepracowany w godzinach nomi- } \\
\text { nalnych za październik }\end{array}$ & $S G N_{-} P A Z=\frac{T W N_{-} P A Z}{T C N_{-} P A Z}$ \\
\hline 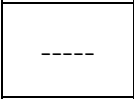 & $\begin{array}{c}\text { Stawka godzinowa wynagrodzenia ogó- } \\
\text { łem za rok }\end{array}$ & $S G O_{-} R O K=\frac{T W O_{-} R O K}{T C O \_R O K}$ \\
\hline ----- & $\begin{array}{c}\text { Stawka godzinowa wynagrodzenia za } \\
\text { czas przepracowany w godzinach nomi- } \\
\text { nalnych za rok }\end{array}$ & $S G N_{-} R O K=\frac{T W N_{-} R O K}{T C N_{-} R O K}$ \\
\hline
\end{tabular}

Źródło: opracowanie własne na podstawie formularza Z-12.

\section{Wyniki oszacowań wskaźnika $G P G$ według województw}

Oszacowań wskaźnika Gender Pay Gap dokonano wykorzystując osiem mierników wynagrodzeń brutto. 
TABELA 2.

Oszacowania wskaźnika Gender Pay Gap

\begin{tabular}{|c|c|c|c|c|c|c|c|c|}
\hline Województwo & 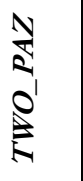 & 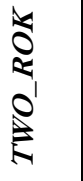 & 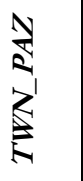 & $\begin{array}{l}z \\
0 \\
z \\
z \\
z \\
z\end{array}$ & 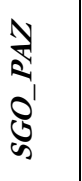 & 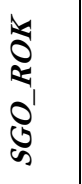 & $\frac{N}{\sum_{0}^{2}}$ & 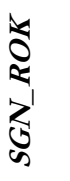 \\
\hline Polska & 17,7 & 17,1 & 17,6 & 16,6 & 7,7 & 6,6 & 7,1 & 5,9 \\
\hline dolnośląskie & 21,9 & 21,9 & 21,1 & 20,8 & 14,1 & 14,1 & 13,3 & 13,4 \\
\hline kujawsko-pomorskie & 9,1 & 7,4 & 9,4 & 7,4 & $-6,8$ & $-9,1$ & $-7,7$ & $-10,3$ \\
\hline lubelskie & 8,4 & 7,9 & 8,9 & 8,0 & $-6,5$ & $-8,0$ & $-7,2$ & $-8,9$ \\
\hline lubuskie & 8,8 & 7,7 & 9,6 & 7,5 & $-5,4$ & $-7,9$ & $-6,4$ & $-9,2$ \\
\hline łódzkie & 13,9 & 12,5 & 14,1 & 12,1 & 1,9 & $-0,4$ & 1,1 & $-1,3$ \\
\hline małopolskie & 17,8 & 17,1 & 18,2 & 17,1 & 7,9 & 6,6 & 7,5 & 6,0 \\
\hline mazowieckie & 20,3 & 20,4 & 20,3 & 20,2 & 15,1 & 14,9 & 14,7 & 14,5 \\
\hline opolskie & 16,6 & 16,0 & 16,9 & 15,8 & 3,3 & 2,0 & 2,4 & 0,9 \\
\hline podkarpackie & 13,9 & 12,8 & 13,8 & 12,4 & $-1,0$ & $-2,8$ & $-1,6$ & $-3,6$ \\
\hline podlaskie & 3,3 & 1,3 & 3,3 & 1,4 & $-14,2$ & $-16,4$ & $-14,9$ & $-17,2$ \\
\hline pomorskie & 16,3 & 15,1 & 16,2 & 14,7 & 5,5 & 3,9 & 4,7 & 2,9 \\
\hline śląskie & 26,0 & 24,8 & 25,4 & 23,9 & 14,6 & 12,9 & 14,2 & 12,3 \\
\hline świętokrzyskie & 11,5 & 9,5 & 11,5 & 9,1 & $-4,5$ & $-7,1$ & $-5,0$ & $-7,9$ \\
\hline warmińsko-mazurskie & 6,3 & 4,5 & 6,4 & 3,9 & $-7,1$ & $-9,7$ & $-8,1$ & $-11,0$ \\
\hline wielkopolskie & 18,8 & 18,6 & 18,7 & 18,3 & 9,9 & 9,3 & 9,2 & 8,4 \\
\hline zachodniopomorskie & 11,7 & 10,6 & 11,8 & 10,3 & $-1,0$ & $-2,6$ & $-1,9$ & $-3,7$ \\
\hline
\end{tabular}

Źródło: opracowanie własne.

Wartości wskaźnika GPG uzyskane na podstawie średnich wynagrodzeń ogółem (stawek godzinowych wynagrodzeń ogółem) oraz wynagrodzeń za czas nominalny (stawek godzinowych za czas nominalny) były do siebie zbliżone, to już porównanie szacunków wskaźnika GPG dla wynagrodzeń ogółem z szacunkami uzyskanymi na bazie stawek godzinowych wykazało znaczne różnice. Przejawiały się one przede wszystkim w pojawieniu się ujemnych wartości wskaźnika, co świadczy o tym, że kobiety osiągały wyższe stawki godzinowe w porównaniu z mężczyznami (w pewnych województwach). Prawdopodobna przyczyną tej sytuacji, że porównując wynagrodzenia roczne i za październik kobiet w stosunku do mężczyzn, uzyskały one średnio niższe wynagrodzenia, a przeciętne stawki godzinowe wskazywały na to, że dla kobiet były one znacznie wyższe niż dla mężczyzn, było poświęcanie przez mężczyzn znacznie większej ilości czasu na pracę aniżeli przez kobiety. Wynikało to głównie ze zwiększonego u kobiet ciężaru obowiązków rodzicielskich. W dalszej konsekwencji mężczyźni osiagali znacznie wyższe, w porównaniu z kobietami, dodatkowe benefity z pracy w postaci premii 
i honorariów, które odniesione do znacznie większej liczby przepracowanych godzin, mimo wszystko dały niższe stawki godzinowe.

Szacunki wskaźnika GPG dla danych rocznych z reguły były niższe w porównaniu z szacunkami dla danych dotyczących października.

Znamienne jest również to, że rozpiętość wartości wskaźnika była znacznie wyższa dla szacunków uzyskanych na podstawie stawek godzinowych w porównaniu z wynagrodzeniami osiaganymi w ciagu roku czy październiku.

Niezależnie od przyjętego miernika wynagrodzeń brutto, najwyższe wartości wskaźnik luki płacowej przyjmował dla województw: śląskiego, dolnośląskiego, mazowieckiego, wielkopolskiego oraz małopolskiego.

RYSUNEK 1.

\section{Gender Pay Gap oszacowany z wykorzystaniem wartości wynagrodzenia} ogółem brutto za październik 2014 roku, według województw

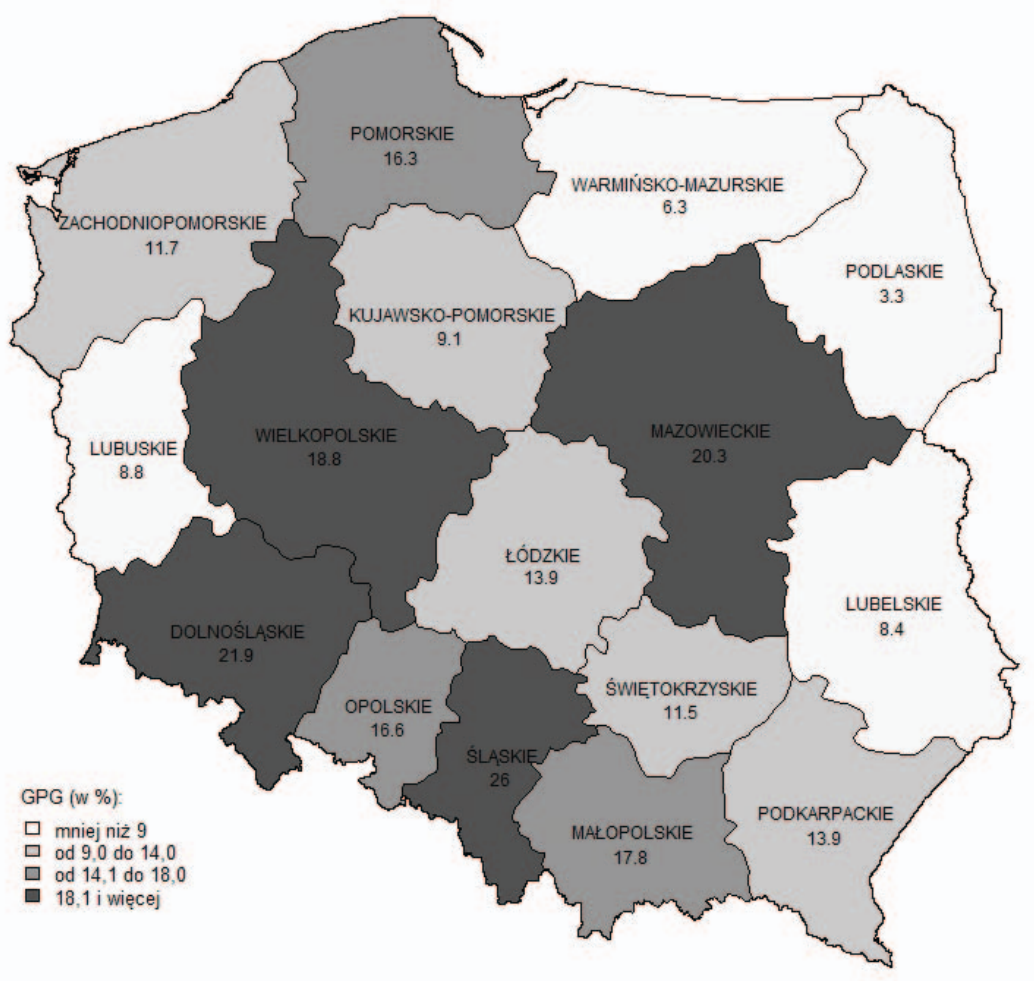

Źródło: opracowanie własne. 
W grupie województw o najwyższych wartościach wskaźnika Gender Pay Gap znalazły się: śląskie $(26,0 \%)$, dolnośląskie $(21,9 \%)$, mazowieckie $(20,3 \%)$ oraz wielkopolskie $(18,8 \%)$. W tych województwach różnice w przeciętnych wynagrodzeniach, mierzonych $T W O \_P A Z$, pomiędzy mężczyznami a kobietami były największe w kraju. W trzech województwach sięgały one ponad $20 \%$. Województwami o najniższej luce płacowej były: podlaskie $(3,3 \%)$, warmińsko-mazurskie $(6,3 \%)$ oraz lubelskie $(8,4 \%)$ i lubuskie $(8,8 \%)$. W pięciu województwach wskaźnik GPG przekroczył wartość dla Polski $(17,7 \%)$.

RYSUNEK 2.

\section{Gender Pay Gap oszacowany z wykorzystaniem wartości wynagrodzenia ogółem brutto za 2014 rok, według województw}

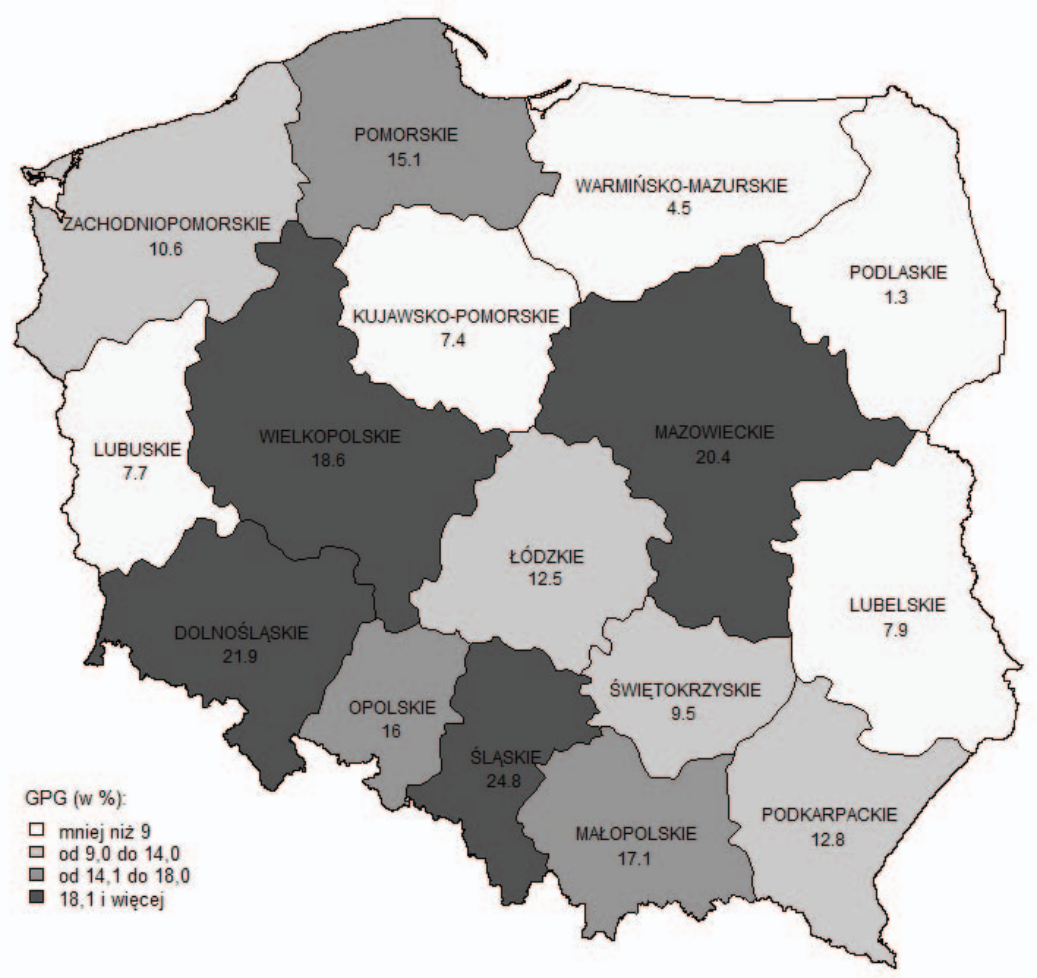

Źródło: opracowanie własne.

W przypadku oszacowań dokonanych z wykorzystaniem TWO_ROK grupę województw o najwyższych wartościach $G P G$ ponownie tworzyły: śląskie $(24,8 \%)$, dolnośląskie $(21,9 \%)$, mazowieckie $(20,4 \%)$ oraz wielkopolskie (18,6\%). Grupa województw 
o najniższej luce płacowej pomiędzy mężczyznami a kobietami składała się z województw: podlaskiego (1,3\%)warmińsko-mazurskiego (4,5\%), kujawsko-pomorskiego $(7,4 \%)$ oraz lubuskiego $(7,7 \%)$ i lubelskiego $(7,9 \%)$.

RYSUNEK 3.

Gender Pay Gap oszacowany z wykorzystaniem stawek godzinowych wynagrodzenia ogółem brutto za październik 2014 roku, według województw

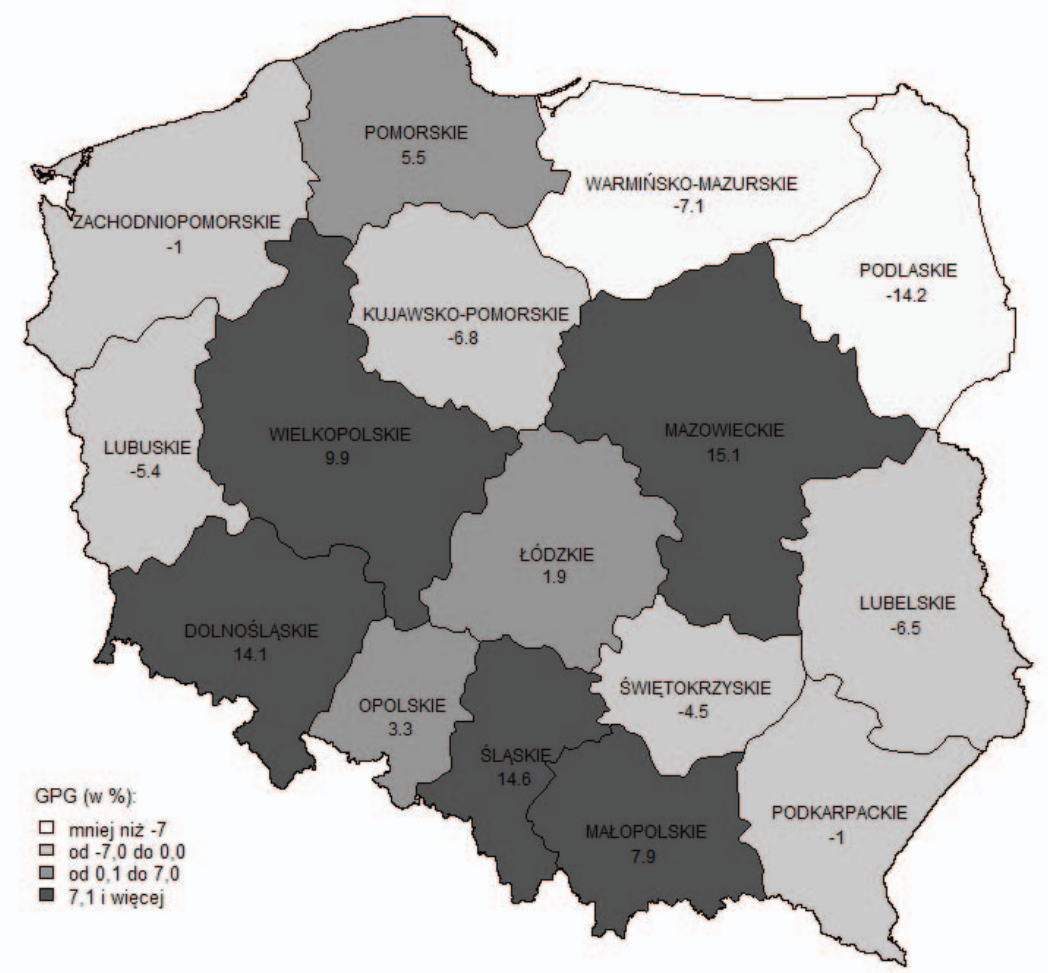

Źródło: opracowanie własne.

Biorac pod uwagę oszacowania wielkości luki płacowej stawek godzinowych wynagrodzeń ogółem brutto za październik (SGO_PAZ), otrzymane wartości GPG prowadzą do odmiennych wniosków aniżeli te uzyskane na podstawie wartości wynagrodzeń ogółem brutto. Po pierwsze, znacznie zwiększyła się różnica pomiędzy najwyższą a najniższą wartością wskaźnika dla województw, osiągając prawie 30 p.p. Po drugie, dla ośmiu województw pojawiły się ujemne oszacowania, co oznacza, że to kobiety osiagały średnio wyższe stawki godzinowe wynagrodzeń w porównaniu z mężczyznami. Najniższą wartość wskaźnika GPG wyznaczono dla województwa podlaskiego, w którym kobiety uzyskiwały średnio wyższe stawki godzinowe w porównaniu z mężczyznami 
o ponad $14 \%$. W trzech województwach różnica ta była stosunkowo mała, tj. w: podkarpackim (-1\%), zachodniopomorskim (-1\%) oraz łódzkim (1,9\%). Województwami o największej luce płacowej były niezmiennie: mazowieckie $(15,1 \%)$ śląskie $(14,6 \%)$, dolnośląskie $(14,1 \%)$ oraz wielkopolskie $(9,9 \%)$. Należy podkreślić, że wartości uzyskane na podstawie stawek godzinowych były znacznie niższe aniżeli te uzyskane na podstawie wynagrodzeń ogółem.

RYSUNEK 4.

Gender Pay Gap oszacowany z wykorzystaniem stawek godzinowych wynagrodzenia ogółem brutto za 2014 rok, według województw

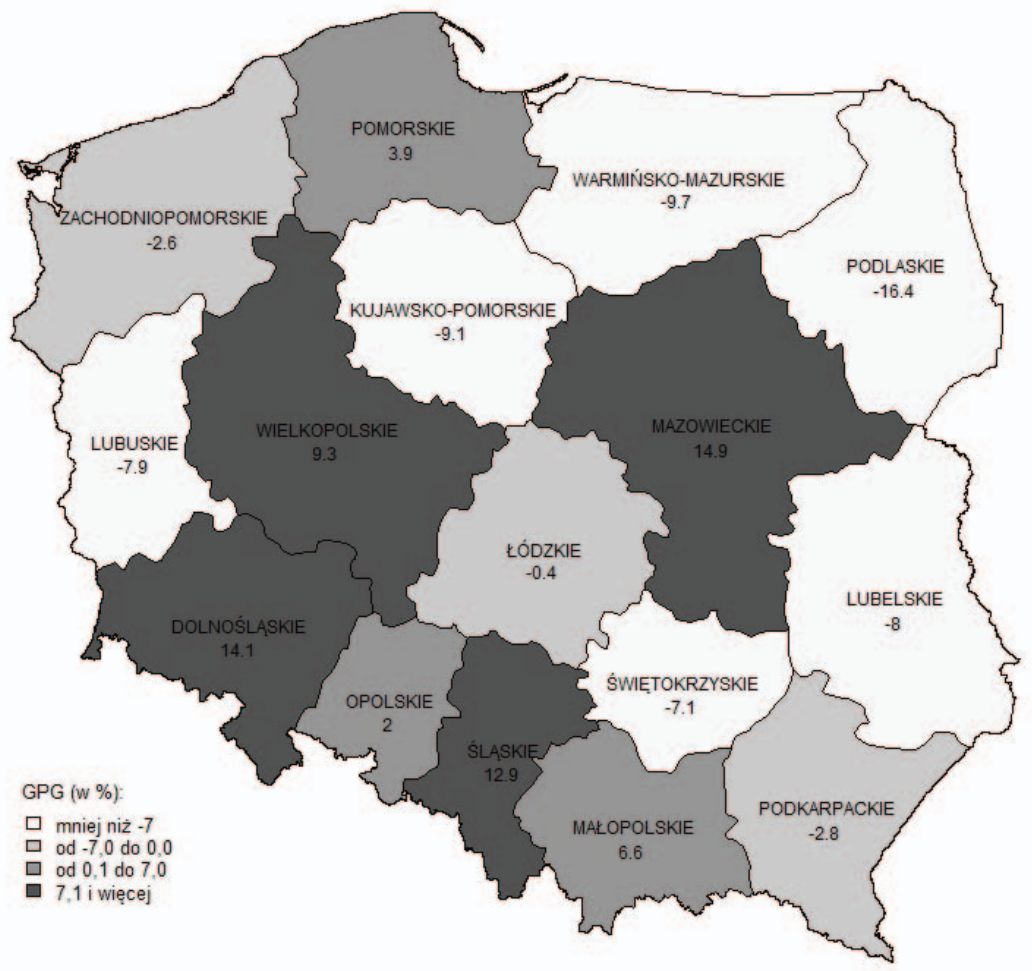

Źródło: opracowanie własne.

Wykorzystanie do oszacowania wskaźnika Gender Pay Gap stawek godzinowych wynagrodzenia ogółem z roku (SGO_ROK) dało ujemne wartości dla dziewięciu województw. Najniższa wartość ponownie dotyczyła województwa podlaskiego $(-16,4 \%)$, a najwyższa znowu mazowieckiego (14,9\%). Zwiększyła się także różnica pomiędzy maksymalną i minimalną wartością wskaźnika - ponad 31 p.p. Nieznaczne różnice 
wystapiły w województwach: łódzkim $(-0,4 \%)$, zachodniopomorskim $(-2,6 \%)$, podkarpackim $(-2,8 \%)$.

\section{Podsumowanie}

Wyznaczone szacunki wskaźnika Gender Pay Gap dla województw dowodzą że jest to miernik, którego wartość jest uzależniona od przyjętej postaci miernika przeciętnych wynagrodzeń mężczyzn i kobiet. Wykazuje on relatywnie dużą wrażliwość na wartości wejściowe i z tego względu nie daje jednoznacznych rozstrzygnięć. Uzyskane wyniki pozwalają wysnuć wniosek, że występują różnice w wynagradzaniu pomiędzy mężczyznami a kobietami w województwach, ale wielkość tych różnic, rozpatrywana w kategoriach przeciętnych, jest silnie uzależniona od danych będących podstawą szacunków.

Jako kierunki dalszych badań należy wskazać: wykorzystanie pozycyjnych (kwantyle wynagrodzeń) mierników wynagrodzeń do szacowania wskaźnika GPG, zastosowanie metod opartych na modelowaniu ekonometrycznym, spożytkowanie metod bazujących na łączeniu danych, użycie rejestrów administracyjnych do analizy luki płacowej, określenie czynników wpływających na wielkość luki płacowej.

\section{Literatura}

Adamchik V.A., Bedi A.S., 2003, Persistence Of The Gender Pay Differential In A Transition Economy, "ISS Working Paper", no. 349, Hague: Institute of Social Studies.

Alksnis C., Desmarais S., Curtis J., 2008, Workforce segregation and gender wage gap: is "women's work" valued as highly as men's?, "Journal of Applied Social Psychology", vol. 38, iss. 6, DOI: 10.1111/j.1559-1816.2008.00354.x.

Baron J. D., Cobb-Clark D. A., 2010, Occupational Segregation and the Gender Wage Gap in private- and public sector employment: A distributional analysis. The Economic Record, "The Economic Society of Australia", vol. 86, iss. 273.

Blinder A., 1973, Wage Discrimination: Reduced Form and Structural Estimates, "The Journal of Human Resources", vol. 8, no. 4, DOI: 10.2307/144855.

Brainerd E., 2000, Women in Transition: Changes in Gender Wage Differentials in Eastern Europe and the Former Soviet Union, "Industrial and Labor Relations Review", vol. 54, iss. 1.

Dyrektywa 2006/54/WE Parlamentu Europejskiego i Rady z dnia 5 lipca 2006 roku, http://www.spoleczenstwoobywatelskie.gov.pl/sites/default/files/2006.54.pdf (data wejścia: 13.05.2017).

Europejska Karta Spoteczna z. 18 października 1961 roku, https://www.mpips.gov.pl/ gfx/mpips/userfiles/File/Spoleczne Prawa Czlowieka/EKS/Europejska Karta Spoleczna - tekst.pdf (data wejścia: 13.05.2017).

Frölich M., 2007, Propensity score matching without conditional independence assumption - with an application to the gender wage gap in the United Kingdom, "Econometrics Journal", vol. 10, iss. 2, DOI: 10.1111/j.1368-423X.2007.00212.x. 
Grajek M., 2003, Gender pay gap in Poland, "Economics of Planning", vol. 36, iss. 1.

Kalinowska-Nawrotek B., 2005, Dyskryminacja kobiet na polskim rynkupracy, Wydawnictwo Akademii Ekonomicznej w Poznaniu, Poznań.

Karta Praw Podstawowych Unii Europejskiej z. 7 grudnia 2000 rok.u, https://bip.ms.gov.pl/ Data/Files/_public/bip/prawa_czlowieka/onz/karta.pdf (data wejścia: 13.05.2017).

Konstytucja Rzeczypospolitej Polskiej z. dnia 2 kwietnia 1997 roku, Dz.U. 1997, Nr 78, poz. 483, http://isap.sejm.gov.pl/DetailsServlet?id=WDU19970780483 (data wejścia: 13.05 .2017$)$.

Konwencja nr 100 Miedzynarodowej Organizacji Pracy z. 29 czerwca 1951 roku, http:/ / prawo.legeo.pl/prawo/konwencja-nr-100-dotyczaca-jednakowego-wynag rodzenia-dla-pracujacych-mezczyzn-i-kobiet-za-prace-jednakowej-wartosci-przyjetaw-genewie-dnia-29-czerwca-1951-r/zal1/?on=1955-09-27 (data wejścia: 13.05.2017).

Lisowska E., 2012, Wynagrodzenia a pleć, [w:] Polityka różnorodności w administracji centralnej, E. Lisowska (red.), Oficyna Wydawnicza Szkoły Głównej Handlowej, Warszawa.

Magda I., Szydłowski A., 2008, Płace w makro i mikroperspektywie, [w:] Zatrudnienie w Polsce 2007 - Bezpieczeństwo na elastycznym rynku pracy, M. Bukowski (red.), Ministerstwo Pracy i Polityki Społecznej, Warszawa.

Miedzynarodowy Pakt Praw Gospodarczych, Spotecznych i Kulturalnych otwarty do podpisu w Nowym Jorku dnia 19 grudnia 1966 rok.u, Dz. U. 1977, Nr 38, poz. 169, http:/ /isap.sejm.gov.pl/ DetailsServlet?id=WDU19770380169 (data wejścia: 13.05.2017).

Newell A., Reilly B., 2001, The genderpay gap in the transition from communism: Some empirical evidence, "Economic Systems", vol. 25, iss. 4.

Nopo H., 2008, Matching as a Tool to Decompose Wage Gaps, "The Review of Economics and Statistics", vol. 90, iss. 2, DOI: 10.1162/rest.90.2.290.

Oaxaca R. L., 1973, Male-Female Wage Differentials in Urban Labor Markets, "International Economic Review”, vol. 14, no. 3, DOI: 10.2307/2525981.

Prz̨eciwdziatanie różnicy w wynagrodzeniu dla kobiet i mę̇çyzn w Unii Europejskiej, 2014, Urząd Publikacji Unii Europejskiej, Luksemburg, http:/ /www.rownoscwbiznesie. mpips.gov.pl/component/jdownloads/send/3-luka-placowa/18-przeciwdzialanieroznicy-w-wynagrodzeniu-dla-kobiet-i-mezczyzn-w-unii-europejskiej-raport-komisjieuropejskiej-2014.html (data wejścia: 14.04.2017).

Russel H., Smyth E., O’Connel P.J., 2010, Gender differences in pay among recent graduates: Private sector employees in Ireland, "Journal of Youth studies", vol. 13, iss. 2, DOI: $10.1080 / 13676260903295083$.

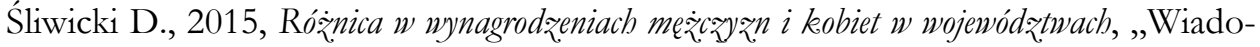
mości Statystyczne", nr 10.

Śliwicki D., Ryczkowski M., 2014, Gender Pay Gap in the micro level - case of Poland, "Quantitative Methods in Economics", vol. XV, no. 1.

Słoczyński T., 2012, Wokół międzynarodowego zróżnicowania międzyptciowej luki płacowej, „Zeszyty Naukowe Kolegium Gospodarki Światowej SGH”, nr 34.

Stanley T., Jarrell S.B., 1998, Gender Wage Discrimination Bias? A Meta-Regression Analysis, "The Journal of Human Resources", vol. 33, no. 4. 
The gender pay gap in the Member States of European Union: quantitative and qualitative indicators. Belgian Presidency Report 2010, http://igvm-iefh.belgium.be/sites/default/ files/downloads/53 - Gender pay gap in the member states of the EU_ENG.pdf (data wejścia: 01.05.2017).

Traktat o funkejonowaniu Unii Europejskiej podpisany w Atenach w dniu 16 kwietnia 2003 roku, http://oide.sejm.gov.pl/oide/?option=com_content\&view=article\&id=14 804\&Itemid=420 (data wejścia: 13.05.2017).

Traktat z. Amsterdamu zmieniajacy Traktat o Unï Europejskiej, Traktaty ustanawiajace W spólnoty Europejskie i niektóre zwiazane z. nimi akty z. 2 października 1997 roku, http://oide.sejm.gov.pl/oide/images/files/dokumenty/traktaty/Traktat_amsterdam ski_PL_1.pdf (data wejścia: 13.05.2017).

Traktaty ryymskie: Traktat ustanawiajacy Europejska Wspólnote Gospodarczq z 25 marca 1957 roku, https://eures.praca.gov.pl/zal/podstawy_prawne/Traktat_rzymski.pdf (data wejścia: 13.05.2017).

Ustawa z dnia 26 czerwca 1974 r. Kodeks pracy, Dz. U. 1974, Nr 24, poz. 141, http:/ / isap.sejm.gov.pl/DetailsServlet?id=WDU19740240141 (data wejścia: 13.05.2017).

Walby S., Olsen W., 2002, The Impact of Women's Position in the Labour Market on Pay and Implications for UK Productivity, Women and Equality Unit, London.

Warren T., Rowlingson K., Whyley C., 2001, Female Finances: gender wage gaps and gender assets gaps, "Work Employment and Society", vol. 15, iss. 3.

Weichselbaumer D., Winter-Ebmer R., 2005, A Meta-Analysis of the International Gender Wage Gap, "The Journal of Economic Surveys", vol. 19, iss. 3. 